УДК 378.041

DOI:

Віталій Цісарук, кандидат педагогічних наук, доцент

кафедри теорії та методики трудового навчання та технологій Кременецької обласної гуманітарно-педагогічної академії імені Тараса Шевченка

Ірина Цісарук, аспірант, асистент кафедри теорії та методики трудового навчання та технологій Кременецької обласної гуманітарно-педагогічної академії імені Тараса Шевченка

\title{
САМООСВІТНЯ КОМПЕТЕНТНІСТЬ МАЙБУТНЬОГО ВЧИТЕЛЯ ТРУДОВОГО НАВЧАННЯ ТА ТЕХНОЛОГІЙ
}

У статті проаналізовано визначення науковцями терміну “самоосвітня компетентність”. Визначено поняття самоосвітня компетентність майбутнього вчителя трудового навчання та технології як якість особистості педагога, щзо характеризується здатністю та готовністю до безперервної самоосвіти під час навчання та у проиесі професійної діяльності. Висвітлено питання формування самоосвітньої компетентності у майбутніх учителів. Охарактеризовано сутність, структуру та функиії самоосвітньої компетентності. Розкрито уміння теоретичного і практичного характеру, якими повинні володіти майбутні вчителі технологій під час організаиії самостійної діяльності.

Ключові слова: самостійна робота; самоосвітня компетентність; професійна діяльність

Jim. 6.

Vitaliy Tsisaruk, Ph.D.(Pedagogy), Associate Professor of the Theory and Methodology of Labor Training and Technologies Department Kremenets Taras Shevchenko Regional Humanitarian-Pedagogical Academy

Iryna Tsisaruk, Postgraduate Student, Assistant of the Theory and Methodology of Labor Training and Technologies Department Kremenets Taras Shevchenko Regional Humanitarian-Pedagogical Academy

\section{SELF-EDUCATION COMPETENCE OFTHE FUTURE TEACHER OF LABOR EDUCATIONAND TECHNOLOGY}

The article reflects the essence, structure and problem of forming the self-educational competence. The "selfeducation competence of the future teacher of labor education and technologies" is defined as the quality of the teacher's personality, characterized by the ability and readiness for the continuous self-education during studying and in the process of professional activity. It is marked that the peculiarity of self-educational competence is forming on the basis of gaining an experience of independent attempts and achievements in self-education, developing its own individual learning system, moving from copying the self-education samples to creating its own model, adding self-education to the student's lifestyle.

The attetion is accented on the development of self-educational competence of the future teachers of labor education and technology, because this specialty requires the constant professionalism, as it directly depends on the multifaceted knowledge, skills and abilities, which in turn are connected with the constantly changing technologies.

The research considers the functions of self-educational competence of the teacher (motivational, developmental, educational, cognitive, methodological, informative, diagnostic-prognostic, communicative, reflexive, adaptive and interactive). The author reveals the theoretical and practical skills that the future teachers of technology have to possess in organizing their own activities.

It is also educed that the effectiveness of forming the self-education competence of future teachers of labor education and technology largely depends on informational support of the educational process. The using of advanced information and communication technologies makes it possible to intensify the students' independent activity and thus increase the level of development of self-education competence.

Keywords: an independent work; the self-educational competence; professional activity.

П остановка проблеми. Інноваційна за змістом і характером динаміка світових тенденцій розвитку суспільства вимагає формування випереджувальної освітньої політики. Серед очікуваних результатів реалізації Національної стратегії розвитку освіти в Україні на 2012 - 2021 рр. - підготовка та виховання кадрів вищої кваліфікації, здатних працювати на засадах інноваційних підходів до організації навчально-виховного процесу, власного творчого безперервного професійного зростання. Увага акцентується на поглибленні компетентнісної парадигми, самостійній освітній діяльності майбутнього фахівця. 


\section{САМООСВІТНЯ КОМПЕТЕНТНІСТЬМАЙБУТНЬОГО ВЧИТЕЛЯ ТРУДОВОГОНАВЧАННЯТАТЕХНОЛОГЙ}

Стратегії самостійного пізнання стають механізмом, який забезпечує можливість вільної реалізації суб'єктів педагогічного процесу, право вибору особистістю індивідуальної траєкторії професійного розвитку. Відповідно, сучасними освітньо-нормативними документами "Про впровадження кредитно-модульної системи організації навчального процесу" (2005) самостійну роботу студента визначено основною формою організації освітньої діяльності в сучасному закладу вищої освіти, а її обсяг регламентується від $1 / 3$ до $2 / 3$ загального навчального часу.

Сучасні вимоги до професійних якостей майбутніх учителів трудового навчання та технологій передбачають запровадження такої освітньої моделі їхньої підготовки, яка б забезпечувалаїх становлення як конкурентоспроможних фахівців із високим рівнем творчого потенціалу, суб'єктів саморозвитку і професійного самовдосконалення, здатних діяти, відповідально вирішувати освітні завдання у безперервно змінних умовах педагогічної реальності.

Аналіз останніх досліджень і публікацій Питання самоосвітньої компетентності досліджували О. Айзенберг, С. Архангельский, Н. Бухлова, Н. Воропай А. Громцева, Г. Гусєв, Ю. Дмитрієв, М. Князева, Н. Коваленко, Л. Колесник, I. Малкін, I. Наумченко, О. Ножовнік, П. Підкасистий, Б. Райский, Г. Сухобска, О. Ястребцева та ін.

Значну увагу проблемі формування самоосвітньої компетентності студентів закладів вищої освіти приділили науковці Л. Вьюшкова, I. Зимня, О. Малихін, Р. Саітова, Є. Чеботарева, I. Преображенська, О. Фоміна та ін.

Проте аналіз психолого-педагогічної літератури показав, що на даний час проблема формування самоосвітньої компетентності у майбутнього вчителя трудового навчання та технологій $є$ недостатньо розглянутою.

Мета статті - розкрити сутність, структуру, а також проблему формування самоосвітньої компетентності майбутнього вчителя трудового навчання та технологій.

Виклад основного матеріалу. Основою викладання у закладі вищої освіти за інноваційною моделлю освіти стає - компетентністний підхід, який полягає, в значній мірі, не в передачі знань від викладача до студента, а у навчанні майбутнього фахівця здобувати знання самостійно. Тому необхідно, щоб викладач виступав організатором навчальної діяльності студента, який під час освітнього процесу перетворює студента із пасивного учасника навчання на основний об'єкт навчальної діяльності. Завдяки такій організації навчального процесу студент самостійно шукає та засвоює інформацію, яка буде необхідною у майбутній професійній діяльності. Таким чином важливо під час професійної підготовки майбутніх педагогів сформувати самоосвітню компетентність. Особливу увагу слід приділити розвиткові самоосвітньої компетентності у майбутніх учителів трудового навчання та технологій, тому що дана спеціальність потребує постійного підвищення професіоналізму, оскільки безпосередньо залежить від багатогранності знань, у свою чергу пов'язаних 3 новітніми технологіями, які постійно змінюються.

Особливістю самоосвітньої компетентності є формування iii на основі набуття досвіду самостійних спроб і досягнень у самоосвітній діяльності, вироблення власної індивідуальної системи навчання, переходу від копіювання зразків самоосвіти до створення власної моделі, долучення самоосвіти до способу життя студента.

Дослідниця О. Фоміна визначає самоосвітню компетентність як якість особистості, що характеризує ї̈ здатність до систематичної самостійної пізнавальної діяльності, спрямованої на продовження власної освіти в загальнокультурному та професійному аспектах [6, 6]. Науковець Н. Воропай розглядає самоосвітню компетентність як одну 3 важливих складових життєвої компетентності, яка являє собою систему здібностей, що забезпечують особистості можливість успішно вирішувати життєві завдання, успішно здійснювати свою життєдіяльність у всіх іiі проявах [3, 31]. Учені Л. Білоусова і О. Кисельова визначають самоосвітню компетентність як складне інтегративне особистісне утворення, яке зумовлює не лише готовність до самоосвітньої діяльності, а й реальну здатність ефективного іiі здійснення 3 метою самовдосконалення та професійного розвитку $[1,12]$

У контексті підготовки майбутнього педагога виділяють такі функції самоосвітньої компетентності:

- мотиваційна (визначає спрямованість і активність майбутнього педагога у сфері педагогічної діяльності, його самоактуалізацію і самореалізацію);

- розвивальна (зумовлює саморозвиток педагогічних та професійно важливих якостей і здібностей);

- виховна (спрямовує процес самовдосконалення майбугнього педагога);

- пізнавальна (спрямовує на систематизацію знань, на пізнання і самопізнання); 


\section{САМООСВІТНЯ КОМПЕТЕНТНІСТЬМАЙБУТНЬОГО ВЧИТЕЛЯ ТРУДОВОГОНАВЧАННЯТА ТЕХНОЛОГЙ}

- методологічна (полягає у спрямуванні діяльності майбутнього педагога на теоретичне осмислення й наукове дослідження педагогічного процесу, особливостей професійного становлення майбутніх фахівців);

- інформативна (орієнтує в потоках різноманітної інформації, допомагає виявляти і відбирати нову, оцінювати значущість або другорядність інформації);

- діагностико-прогностична (спрямовує майбутнього педагога на оволодіння і реалізацію методик моніторингу педагогічного процесу, професійного розвитку, рівня становлення власної компетентності самоосвіти);

- комунікативна (зумовлює активність у сферах міжособистісної та педагогічної комунікації);

- рефлексивна (полягає у самозвітуванні щодо результативності самоосвітньої діяльності, визначенні напрямів їі удосконалення);

- адаптаційна (спрямовує ефективну адаптацію майбутнього педагога у сфері педагогічної діяльності в інформаційному суспільстві);

- інтерактивна (формує активну самостійну і творчу діяльність особистості, яка веде до іiі саморозвитку, самореалізаціі) $[1,12]$.

Розгляд та аналіз різних визначень поняття “самоосвітня компетентність", дали змогу сформулювати узагальнене визначення відповідно до нашого дослідження. Отже, під “самоосвітньою компетентністю майбутнього вчителя трудового навчання та технологій” ми розуміємо якість особистості педагога, що характеризується здатністю та готовністю до безперервної самоосвіти під час навчання та у процесі професійної діяльності.

Залежно від конкретних цілей під час організації самостійної діяльності майбутні вчителі технологій мають володіти такими уміннями теоретичного і практичного характеру:

- робота 3 навчально-методичним та нормативно-правовим матеріалом;

- планування, аналіз і структурування процесу засвоєння та закріплення знань;

- проведення самооцінки та самоаналізу;

- розвиток аналітичних здібностей студентів;

- закріплення й удосконалення фахових знань;

- обирання теми самостійної роботи;

- формулювання цілі й задачі;

- обирати метод розв'язання поставленої задачі;

- оформлення й захист результатів самостійної роботи;

- розв'язання загальнопрофесійних задач [5].

Самоосвітня компетентність є однією із основних компетентностей, що формується завдяки систематичному та послідовному самонавчанню, розвиваючи всебічно гармонійно розвинену особистість - фахівця. Структура самоосвітньої компетентності базується на основі:

- розуміння особистих потреб на підставі самоаналізу, самопізнання, самообліку сильних і слабких сторін своєї діяльності;

- розробки та виконання програми самоосвіти 3 урахуванням особистих потреб і потреб суспільства;

- упорядкування своїх знань, знаходження зв'язків між ними;

- критичного оцінювання будь-якої отриманої інформації, вироблення особистої позиціїу процесі здобуття певних знань;

- розв'язування різноманітних проблем на основі здобутих самостійно знань;

- гнучкості застосування знань, умінь і навичок в умовах швидких змін;

- представлення, обгрунтування та захисту отриманого результату;

- знаходження нестандартних нових рішень на основі самостійно здобутих знань;

- організації особистих прийомів самонавчання;

- використання для отримання інформації різноманітних баз даних, джерел інформації;

- використання нових технологій інформації та комунікації;

- подолання труднощів, невпевненості, ліні;

- адекватного оцінювання значення здобутих знань у своїй діяльності;

- співробітництва 3 іншими людьми, здобування знань шляхом колективної діяльності;

- прийняття рішення на основі співробітництва, толерантного ставлення до опозиційної точки зору;

- відповідальності за організацію своєї самоосвітньої роботи;

- постійного самоаналізу та самоконтролю за самоосвітньою діяльністю;

- удосконалення своїх результатів, отриманих під час самоосвіти $[4,60]$.

Дослідниця Н. Бухлова пропонує визначити самоосвітню діяльність вчителя як сукупність декількох “само" [2, 32 - 33]:

- самооцінка - вміння оцінювати свої можливості;

- самооблік - вміння брати до уваги наявність своїх якостей;

- самовизначення - вміння вибирати, усвідомити свої інтереси;

- самоорганізація - вміння знайти джерело пізнання й адекватні своїм можливостям форми самоосвіти; планувати, організувати навчальну діяльність; 


\section{САМООСВІТНЯ КОМПЕТЕНТНІСТЬМАЙБУТНЬОГО ВЧИТЕЛЯ ТРУДОВОГО НАВЧАННЯТА ТЕХНОЛОГІЙ}

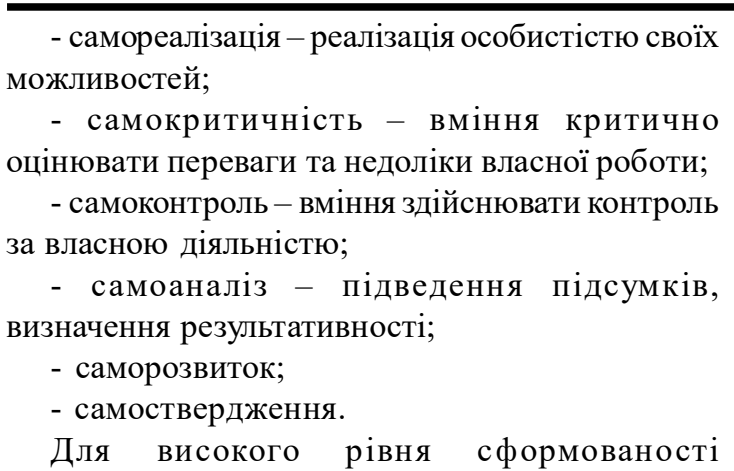
самоосвітньої компетентності важливо майбутньому фахівцю, зокрема і вчителю трудового навчання та технологій, розвинути у собі вище згадану сукупність "само".

Варто відзначити, що ефективність формування самоосвітньої компетентності у майбутніх учителів трудового навчання та технологій значною мірою залежить від інформаційної підтримки освітнього процесу. Саме використання новітніх інформаційнокомунікаційних технологій дає можливість активізувати самостійну діяльність студентів та відповідно підвищити рівень сформованості самоосвітньої компетентності. Одним із видів проведення індивідуальної та самостійної роботи зі студентами $є$ використання сучасних технологій навчання, що запроваджуються у закладах вищої освіти. Це модульне динамічне об'єктноорієнтоване середовище для навчання Moodle, яке створюється викладачами на допомогу студентам і базується на використанні сучасних інформаційних технологій і комп'ютерних засобів навчання.

Висновки. Теоретичний аналіз наукових праць та публікацій дозволив зробити висновок про актуальність визначеної нами теми, недостатність іiі розв'язання і необхідність подальшої розробки. Самоосвітня компетентність $€$ однією із ключових компетентностей майбутнього вчителя трудового навчання та технологій, а тому іï формування $\epsilon$ одним 3 основних завдань освітнього процесу вищої школи. Сформованість самоосвітньої компетентності залежить від багатьох чинників та умов, виконання яких дозволить отримати висококваліфікованого фахівця, здатного не тільки якісно готувати матеріали до теоретичних та практичних занять, а й вивчати, опановувати та використовувати нові методи та форми навчання, тобто самовдосконалюватись. Подальші розвідки вбачаємо у розробці наскрізної програми організації самостійної роботи майбугніх вчителів трудового навчання та технологій.

\section{ЛІТЕРАТУРА}

1. Білоусова Л. І., Кисельова О. Б. Технологія формування у майбутніх педагогів компетентності самоосвіти 3 використанням потенціалу інформаційно-навчального середовища / Л.І. Білоусова, О.Б. Кисельова //Інформаційні технології в освіті: [зб. наук. праць]/Гол. ред. Співаковський О.В. - Херсон: Видавництво ХДУ, 2009. - Випуск III. - С. 11-20.

2. Бухлова Н. В. Організація освітньої діяльності / Н. В. Бухлова. - Х. : ВГ Основа, 2003. $-64 \mathrm{c}$.

3. Воропай Н. Становлення поняття "самоосвітня компетентність” у науковометодичній літературі / Н. Воропай // Науковий часопис Національного педагогічного університетуімені М.П. Драгоманова: Теорія і практика навчання та виховання ; Нац. пед. ун-т ім. М. П. Драгоманова. - К., 2010. Серія 17. - С. 27-32.

4. Педагогика: Большая современная энциклопедия / [сост. Е. С. Рапацевич]. - Минск.: “Соврем. Слово", 2005. -720 с

5. Перегудова В. І. Формування самоосвітньої компетентності майбутнього вчителя технологій [Електронний ресурс] / В. І. Перегудова - Режим доступу: http://www.rusnauka.com/44_NIEK_2015/ Pedagogica/5 203402.doc.htm

6. ФоминаЕ.Н. Формирование самообразовательной компетентности студентов на основе применения модульной технологии (на примере средних профессиональных учебных заведений): автореф. дис. на соискание учен. степени канд. пед. наук: спец. 13.00.08 “Теория и методика профессионального образования" / Е. Н. Фомина. - Волгоград, 2007. - 24 с.

\section{REFERENCES}

1. Bilousova, L. I. \& Kyselova, O.B. (2009). Tekhnolohiia formuvannia u maibutnikh pedahohiv kompetentnosti samoosvity $z$ vykorystanniam potentsialu informatsiinonavchalnoho seredovyshcha [Technology of forming future educators competence of selfeducation using the potential of the informationlearning environment]. Information technologies in education: Sb. sciences works. Spivakovskyi O.V. (Ed.). Kherson: KhDU Publ., vol. III, pp. 11-20. [in Ukrainian].

2. Bukhlova, N. V. (2003). Orhanizatsiia osvitnoi diialnosti [Organization of educational activities]. Kharkiv: VH Osnova Publ., 64 p. [in Ukrainian]

3. Voropai, N. (2010). Stanovlennia poniattia "samoosvitnia kompetentnist" u naukovometodychnii literature [Formation of the concept of "self-educational competence" in scientific methodological literature]. Scientific journal of the M. P. Drahomanov National Pedagogical University: 
Theory and Practice of Education. Kyiv, Seria 17, www.rusnauka.com/44_NIEK_2015/Pedagogica/ pp. 27-32. [in Ukrainian].

4. Rapatsevich, Ye. S. (2005). Pedagogika: Bolshaya sovremennaya entsiklopediya [Pedagogy: Large modern encyclopedia]. Minsk: "Sovrem. Slovo", 720 p. [in Russian].

5. Perehudova, V. I. Formuvannia samoosvitnoi kompetentnosti maibutnoho vchytelia tekhnolohii [Formation of self-educational competence of the future teacher of technologies]. Available at: http://

5_203402.doc.htm. [in Ukrainian].

6. Fomina, Ye. N. (2007). Formirovanie samoobrazovatelnoy kompetentnosti studentov na osnove primeneniya modulnoy tekhnologii (na primere srednikh professionalnykh uchebnykh zavedeniy) [Formation of selfeducational competence of students on the basis of application ofmodular technology (on an example ofaverage professional educational institutions)]. Extended abstract of candidate's thesis. Volgograd, 24 p. [in Russian].

Стаття надійшла до редакції 14.05.2018

УДК 378.147

DOI:

Інна Форостюк, кандидат педагогічних наук, доиент кафедри сучасних європейських мов Національного університету фіскальної служби України

\section{ПІДВИЩЕННЯ МОТИВАЦІЇ МОЛОДІ ДО ВИВЧЕННЯ ІНОЗЕМНИХ МОВ У ЗАКЛАДАХ ВИЩОЇ ОСВІТИ}

У статті розглянуто поняття мотивачії, визначені зовнішні та внутрішні мотивачійні складові, а також виділено у результаті аналізу проведеного опитування, які з даних складових грають головну роль у процесі вивчення іноземних мов студентами закладів вищої освіти. Розглянуті сучасні методи посилення інтересу молоді до іноземних мов, зокрема можливості використання Інтернету та платформи Mооdle. Описані найбільш цікаві види діяльності, які пропонує платформа, та зовнішні ресурси, корисні для використання у процесі викладання іноземних мов.

Ключові слова: вища школа; мотиваџія; комунікаџія; інформаційні технологї̈; ресурс; соціальний конструктивізм.

Jim. 5.

Inna Forostyuk, Ph.D.(Pedagogy), Associate Professor of the Modern European Languages Department National University of Fiscal Service of Ukraine

\section{IMPROVING MOTIVATION OF YOUNG PEOPLE TO STUDY FOREIGN LANGUAGES AT HIGHER EDUCATION INSTITUTIONS}

The article considers the definition of the motivation as the formed interest of students to receive significant achievements on the subject as a result of the professional activity of the teacher. It also underlines the motivation external and internal constituents and distinguishes, basing on the data of the questioning, and points out at those of them which play the main part in the process of learning foreign languages by the university students. It was found out that the improving of the career prospects and need to communicate easily with people from the foreign countries are the leading internal motives for young people today. The assessment and avoidance of troubles at the university, in spite of being the leading external motivators of the education system, play the least role for the questioned groups of students. These facts have to obviously influence on the choice of methods of teaching at high school in contemporary situation.

The article describes the aspects of providing language learning at the non-linguistic higher educational institutions using the educational platform Moodle. The philosophical approach of the platform is guided by social constructionist pedagogy. From a constructivist point of view, people actively "construct" new knowledge as they interact with their environment. At the same time constructionism asserts that learning is particularly effective when building and presenting something for others to experience.

The paper also presents the most fruitful types of activities using by the teachers working with Moodle, which help achieve better results of the English learning process. The author considers such appropriate activities for teaching English using the next Moodle resources as Glossary, Forum and Chat. Hot Potato, as an external resource, is presented as an extremely useful one for constructing the interactive tasks and getting the better results of the learning process.

Keywords: a high school; a motivation; communication; information technology; a resource; social constructivism.

П остановка проблеми. На сучасному етапі Україна рухається в напрямку активної співпраці з європейським та світовим співтовариством, тому особлива увага приділяється успішному оволодінню студентами іноземними мовами. Навички іншомовної 